\title{
Penerapan Metode Probing Prompting \\ Untuk Meningkatkan Aktivitas dan Hasil Belajar Matematika Mahasiswa AMIK Mitra Gama
}

\author{
Application of the Probing Prompting Method \\ To improve Mathematics Learning Activities and Learning Outcomes \\ at Amik Mitra Gama
}

Novidawaty Tambunan

\author{
Staf Pengajar Matematika di AMIK MG Duri Riau \\ tambunannovidawaty@gmail.com
}

\begin{abstract}
In attending mathematics lectures, new students are often passive due to the non-uniform background of understanding concepts and adjustment factors for the new campus environment. This research is a Classroom Action Research (CAR) that aims to determine the increase in activity and learning outcomes of Discrete Mathematics in the first semester students of the Computer Management Skills Program to apply the Probing Prompting learning method. The research was conducted on 2018/2019 odd semester students with a total of 30 students. Data were collected through observation and learning outcomes tests. The application of the probing prompting method on the subject of the Matrix can increase the learning activities of new students; it can be seen that the average value of student learning activities from cycle I to cycle II has increased significantly. Student mathematics learning outcomes on the Matrix subject also experienced a significant increase from cycle I to cycle II. It can be concluded that the use of the probing prompting learning model in mathematics learning in the Matrix subject can increase student activity and learning outcomes.
\end{abstract}

Keywords: Learning activities, learning outcomes, mathematics, probing prompting

\begin{abstract}
Abstrak
Dalam mengikuti perkuliahan matematika, mahasiswa baru sering kali pasif dikarenakan latar belakang kemampuan pemahaman konsep yang tidak seragam dan masih adanya faktor penyesuaian dengan lingkungan kampus yang baru. Penelitian ini merupakan Penelitian Tindakan Kelas (PTK) yang bertujuan untuk mengetahui peningkatan aktivitas dan hasil belajar Matematika Diskrit pada mahasiswa semester pertama Program Keahlian Manajemen Komputer terhadap penerapan metode pembelajaran Probing Prompting. Penelitian dilakukan pada mahasiswa semester ganjil 2018/2019 dengan jumlah siswa 30 orang. Teknik pengumpulan data berupa observasi dan tes hasil belajar. Penerapan metode probing prompting pada pokok bahasan Matriks dapat meningkatkan aktivitas belajar mahasiswa baru, terlihat pada nilai rata-rata aktivitas belajar mahasiswa dari siklus I ke siklus II yang meningkat secara signifikan. Hasil belajar matematika mahasiswa pada pokok bahasan Matriks juga mengalami peningkatan yang signifikan dari siklus I ke siklus II. Dapat disimpulkan bahwa penggunaan model pembelajaran probing prompting pada pembelajaran matematika pokok bahasan Matriks dapat meningkatkan keaktifan dan hasil belajar mahasiswa.
\end{abstract}

Kata Kunci: Aktivitas pembelajaran, hasil belajar, matematika, probing prompting 


\section{PENDAHULUAN}

Salah satu indikator dalam mengukur tingkat keberhasilan perkuliahan dalam hal ini perkuliahan matematika adalah hasil belajar. Matematika sebagai salah satu cabang ilmu-ilmu dasar, memegang peranan yang penting dalam mengembangkan kemampuan berpikir siswa, baik kemampuan berpikir dalam matematika ataupun dalam bidang-bidang lainnya (Susanti, 2017). Oleh karena itu hasil belajar Matematika memiliki potensi untuk mempengaruhi pencapaian hasil belajar pada mata kuliah yang lainnya. Sebagai salah satu mata kuliah dasar umum, perkuliahan matematika di Akademi Manajemen Informatika Komputer (AMIK) Mitra Gama biasanya diberikan langsung kepada mahasiswa pada semester pertama. Proses perkuliahan ini sering mengalami kendala dimana mahasiswa masih enggan untuk berperan aktif dalam perkuliahan sehingga proses belajar cenderung berlangsung dengan pasif. Hal ini cukup menjadi tantangan bagi pengajar (dosen) dimana pengajar harus melakukan aktifitas yang jauh lebih tinggi daripada aktifitas belajar peserta didik (mahasiswa). Kondisi tersebut bukanlah kondisi belajar yang efektif, sebagaimana diungkapkan oleh Eggen dan Kaucha (Faulia, 2019) yang mengemukakan bahwa efektivitas pembelajaran ditandai dengan keaktifan siswa dalam pembelajaran, khususnya dalam pengorganisasian dan penemuan informasi.

Adanya tantangan atau permasalahan dalam proses perkuliahan tersebut menyebabkan perlunya usaha perbaikan atau tindakan untuk mengatasinya. Salah satu upaya yang dapat dilakukan untuk meningkatkan aktifitas dan hasil belajar adalah menggunakan model pembelajaran yang sesuai. Dalam hal ini model pembelajaran yang dibutuhkan adalah model yang memberikan kesempatan kepada mahasiswa untuk membangun pengetahuan dan keaktifan belajar. Salah satu model pembelajaran yang dapat dijadikan solusi adalah model pembelajaran probing prompting. Menurut (Malika, 2019) dampak positif dari strategi probing prompting diantaranya meningkatkan keaktifan, kemampuan berpikir kreatif, kemampuan komunikasi serta menumbuhkan keterampilan dan keberanian mahasiswa.

Secara umum pembelajaran probing prompting adalah serangkaian pertanyaan yang sifatnya menuntun dan menggali. Melalui proses tersebut, diharapkan dapat mewujudkan proses berpikir yang mengaitkan pengetahuan sebelumnya dengan pengetahuan baru yang sedang dipelajari. Menurut Swarjawa dkk., (2013) probing prompting adalah suatu model pembelajaran yang berpusat pada peserta didik (student centered). Model pembelajaran ini sesuai dengan paham konstruktivis yang memberikan keleluasaan pada peserta didik untuk aktif mengkonstruksi pengetahuan sendiri. Dosen hanya menjadi fasilitator dan mediator dalam setiap pembelajaran.

Pembelajaran probing prompting dapat membuat suasana belajar lebih aktif karena proses tanya jawab yang dilakukan dengan cara menunjuk mahasiswa secara acak sehingga setiap mahasiswa mau tidak mau harus berpartisipasi aktif dalam pembelajaran. Mahasiswa tidak bisa menghindar dari proses pembelajaran, karena setiap saat ia bisa dilibatkan dalam proses tanya jawab. Selain itu mahasiswa harus fokus pada penyelesaian masalah atau pertanyaan yang memandu mereka memahami konsep dan prinsip yang terkait dengan materi pelajaran Pratiwi dkk., (2019).

Sulistiyono (2011) menyatakan bahwa pelaksanaan pembelajaran probing prompting dapat diawali dengan menghadapkan mahasiswa pada situasi baru, kemudian dilanjutkan dengan diskusi 
dan pengajuan pertanyaan oleh dosen. Mahasiswa kemudian diberi waktu untuk merumuskan jawaban dan menjawab pertanyaan, sedangkan mahasiswa yang lain memberi tanggapan atas jawaban mahasiswa tersebut. Selanjutnya dosen mengajukan pertanyaan akhir kepada mahasiswa untuk menunjukkan bahwa indikator pembelajaran benar-benar telah dipahami dan yang terakhir mahasiswa memberi kesimpulan atas materi pelajaran yang diberikan dengan bimbingan dosen. Pembelajaran dapat diiringi dengan humor agar mahasiswa tidak pasif dan keaktifan seluruh peserta didik dalam perkuliahan dapat tercapai. Dengan demikian, secara teoritis penerapan model probing prompting diyakini dapat meningkatkan keaktifan mahasiswa dalam perkuliahan matematika dan pada akhirnya akan berdampak pada peningkatan hasil belajar matematika mahasiswa.

Beranjak dari pemaparan tersebut, maka dilakukan Penelitian Tindakan Kelas (PTK) yang bertujuan untuk mengetahui peningkatan aktivitas dan hasil belajar matematika pada mahasiswa semester pertama program keahlian Manajemen Komputer melalui penerapan metode pembelajaran probing prompting pada materi matriks.

\section{METODE PENELITIAN}

Penelitian ini merupakan penelitian tindakan kelas yang dilaksanakan di AMIK Mitra Gama Duri Kecamatan Mandau, Kabupaten Bengkalis, Provinsi Riau semester ganjil tahun pelajaran 2018/2019. Subjek pada penelitian ini adalah mahasiswa semester pertama kelas pagi Manajemen Informatika (1PMI) yang berjumlah 30 orang. Penelitian ini dilaksanakan dari tanggal 11 Oktober sampai dengan 11 November 2018. Objek dalam penelitian ini adalah penerapan metode probing prompting untuk meningkatkan aktivitas dan hasil belajar matematika.
Penelitian tindakan kelas memiliki empat tahapan (Gambar 1) yaitu: Perencanaan, Pelaksanaan, Pengamatan, Refleksi (Arikunto, 2014).

Pada awal siklus terlebih dahulu diadakan pretest untuk mengetahui tingkat kemampuan mahasiswa sebelum diterapkannya model pembelajaran probing prompting. Selanjutnya siklus II dilaksanakan setelah melihat hasil refleksi pada siklus I. Hasil refleksi selanjutnya dijadikan pedoman untuk melakukan perbaikan-perbaikan pada siklus berikutnya (jika diperlukan).

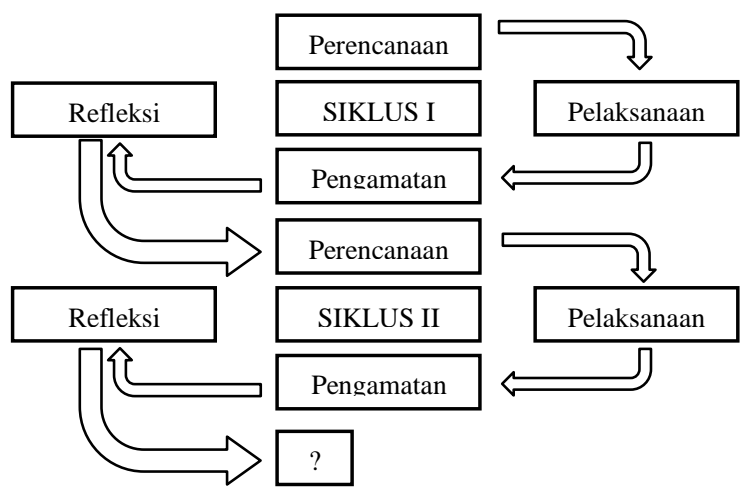

Gambar 1. Siklus Prosedur Penelitian

Adapun pelaksanaan tindakan kelas yang dilakukan selama dua siklus terdiri dari empat kegiatan utama: i) melakukan observasi kelas perkuliahan; dosen yang mengajar dan mahasiswa yang menjadi subyek penelitian. ii) melakukan proses pembelajaran dengan menggunakan metode pembelajaran probing prompting. Aktivitas belajar mahasiswa diamati pada saat mahasiswa bertanya dan menjawab pertanyaan. Sebelumnya dijelaskan terlebih dahulu cara kerja metode pembelajaran probing prompting yang digunakan. iii) setelah proses perkuliahan dengan metode probing prompting selesai maka mahasiswa diberikan tes dengan tujuan untuk mengetahui apakah hasil belajar mahasiswa mengalami peningkatan. iv) melakukan refleksi dengan melihat hasil observasi aktivitas mahasiswa dan hasil tes belajar mahasiswa yang dijadikan sebagai dasar 
untuk merancang pelaksanaan siklus berikutnya.

Untuk mengetahui gambaran tentang pengetahuan awal dan hasil belajar akhir dapat dilihat dari data pretest dan posttest. Tes berbentuk pilihan berganda yang terdiri dari empat pilihan. Setiap pilihan mempunyai satu jawaban yang benar dan tiga pengecoh. Setiap butir yang dijawab benar diberi nilai satu dan yang salah diberi nilai nol.

Selanjutnya untuk aktivitas dan hasil belajar dilakukan dengan menganalisis nilai rata-rata tes. Kategori penilaian tes dilakukan berdasarkan standar penilaian yang dilakukan kampus sebagai berikut.

Kriteria penilaian skor hasil belajar :

Persentase skor $=\frac{\text { skor yang diperoleh siswa }}{\text { jumlah skor }} \times 100 \%$

Hasil kriteria penilaian skor dikategorikan sebagai berikut :

$\begin{array}{ll}90 \%-100 \% & \text { (Sangat Baik) } \\ 80 \%-89 \% & \text { (Baik) } \\ 75 \%-79 \% & \text { (Cukup) } \\ <74 \% & \text { (Kurang Baik) }\end{array}$

\section{HASIL DAN PEMBAHASAN}

Penelitian ini dilakukan dengan menerapkan metode pembelajaran probing prompting. Sebelum penelitian terlebih dahulu dilakukan pretest pada mahasiswa. Pretest ini terdiri dari 25 soal yang telah diujicobakan terlebih dahulu pada mahasiswa semester pertama kelas malam Manajemen Komputer (1MMI) AMIK Mitra Gama, Duri. Setelah pretest dilakukan maka proses perkuliahan dilakukan dengan menerapkan metode pembelajaran probing prompting pada mata kuliah matematika. Pada akhir siklus satu, mahasiswa kembali diuji dengan posttest untuk mengetahui peningkatan hasil belajar mahasiswa. Setelah selesai maka dilakukan analisis dan rekapitulasi data (Tabel 1).

Tabel 1. Hasil Belajar dan Hasil Tes Mahasiswa Siklus I dan Siklus II

\begin{tabular}{|c|c|c|c|c|c|}
\hline & & Ketunta & & $\begin{array}{r}\text { tegori } \mathrm{H} \\
\text { (oran }\end{array}$ & sil Tes \\
\hline No & iklus & $\begin{array}{l}\text { san } \\
(\%)\end{array}$ & Baik & Cukup & Kurang \\
\hline 1. & I & 65,2 & 7 & 10 & 13 \\
\hline 2. & II & 93,1 & 15 & 13 & 2 \\
\hline
\end{tabular}

Setelah dilakukan pembelajaran selama dua pertemuan pada siklus satu dengan penerapan metode belajar probing prompting diperoleh hasil posttest yang meningkat. Sebanyak 17 mahasiswa $(65,2 \%)$ dinyatakan tuntas, sedangkan 13 mahasiwa $(34,8 \%)$ dinyatakan tidak tuntas. Tetapi persentase kelulusan ini masih dibawah dari nilai indikator keberhasilan mahasiswa yaitu $75 \%$. Siklus ke dua dilaksanakan dalam dua kali pertemuan. Setelah dilakukan pembelajaran selama dua kali perkuliahan dengan penerapan metode pembelajaran probing prompting hasilbelajarnya juga meningkat. Hal tersebut ditandai dengan meningkatnya hasil posttest yaitu sebanyak 28 mahasiswa $(93,1 \%)$ dinyatakan tuntas sedangkan dua mahasiswa (6,9\%) dinyatakan tidak tuntas. Persentase kelulusan yang diperoleh pada siklus kedua adalah $93,1 \%$.

Tabel 2. Hasil Observasi Aktifitas Mahasiswa dan Hasil Tes Mahasiswa Siklus I dan Siklus II

\begin{tabular}{|c|c|c|c|c|}
\hline \multirow{2}{*}{ No Siklus } & \multirow{2}{*}{$\begin{array}{c}\text { Aktivitas } \\
\qquad(\%)\end{array}$} & \multicolumn{3}{|c|}{ Kategori Hasil Tes (orang) } \\
\hline & & Baik & Cukup & Kurang \\
\hline 1. I & 65,4 & 3 & 14 & 13 \\
\hline 2. II & 89,3 & 15 & 13 & 2 \\
\hline
\end{tabular}

Berdasarkan data hasil observasi mahasiswa serta hasil tes mahasiswa siklus satu dan siklus dua (Tabel 2), dapat 
disimpulkan bahwa aktivitas mahasiswa selama mengikuti proses pembelajaran siklus kedua dengan menggunakan metode probing prompting mengalami peningkatan. Keaktifan mahasiswa pada siklus satu sebesar $65,4 \%$ meningkat menjadi $89,3 \%$ pada siklus ke dua. Peningkatan aktivitas mahasiswa dari siklus satu ke siklus kedua nilai mahasiswa juga diikuti dengan peningkatan rata-rata nilai mencapai 83,55 dengan rata-rata komulatif kelas 75. Dengan demikian dapat disimpulkan bahwa pembelajaran di kelas berlangsung dengan aktif.

Pada penelitian sebelumnya yang dilakukan oleh Megariati (2014) secara umum penggunaan teknik probing prompting dalam pembelajaran matematika pada materi turunan fungsi dapat meningkatkan hasil belajar siswa secara signifikan. Sejalan dengan itu, Murtiyasa (2016) mengungkapkan bahwa yang dimaksud aspek komunikasi dan kolaborasi pada pembelajaran matematika adalah siswa harus mampu berkomunikasi pada lingkup yang luas pada berbagai kelompok dan lingkungan yang berbeda. Selain itu, Mutmainnah dkk., (2016) menyatakan bahwa penerapan teknik pembelajaran probing prompting dapat meningkatkan hasil belajar fisika pada siswa kelas VIIIa SMP Negeri I Banawa Tengah.

Adapun keberhasilan yang diperoleh pada siklus kedua ini adalah berupa peningkatan aktivitas mahasiswa dalam pembelajaran serta meningkatnya pemahaman mahasiswa mengenai materi yang dipelajari. Dengan menerapkan metode probing prompting, mahasiswa baru (semester pertama) sudah dapat berkomunikasi dan berinteraksi dengan teman-teman sekelasnya dengan baik. Hal ini dapat diketahui dari hasil observasi siklus I dan siklus II selama perkuliahan di kelas.
Perkuliahan dengan metode pembelajaran probing prompting membuat mahasiswa semakin memahami mata kuliah matematika. Mahasiswa lebih antusias dalam belajar karena proses pembelajaran dikombinasikan juga dilakukan dengan tanya jawab antar mahasiswa. Berdasarkan hasil yang diperoleh pada siklus dua, dapat disimpulkan bahwa siklus selanjutnya tidak perlu dilakukan. Penerapan pembelajaran metode probing prompting pada siklus dua sudah dapat meningkatkan aktivitas dan hasil belajar mahasiswa semester pertama kelas pagi Manajemen Komputer (1PMI) AMIK Mitra Gama Tahun Ajaran 2018/2019.

\section{KESIMPULAN}

Berdasarkan penelitian dapat disimpulkan bahwa hasil belajar dan aktivitas mahasiswa dalam pembelajaran probing prompting pada siklus I tidak mencapai standar minimal yang diharapkan, sehingga perlu dilakukan siklus selanjutnya (siklus dua). Pada siklus II, metode pembelajaran probing prompting dapat meningkatkan hasil belajar dan aktivitas mahasiswa pada mata kuliah matematika pada mahasiswa semester pertama kelas pagi manajemen komputer (1PMI) AMIK Mitra Gama Tahun Ajaran 2018/2019.

\section{DAFTAR PUSTAKA}

Arikunto, S. (2014). Prosedur Penelitian Suatu Pendekatan Praktik. Journal of Research in Personality. Jakarta: Rieneka Cipta.

Faulia, I. (2019). Efektivitas Metode Probing dan Prompting Terhadap Kekatifan Siswa Kompetensi Keahlian Teknik Elektronika Industri. Dinamika Pendidikan, 9(2).

Malika, H. B. (2019). Penerapan Strategi Probing Prompting Pada Mata Kuliah Kalkulus 3 Program Studi Teknik 
Sipil. Jurnal Sangkareang Mataram, 5(4), 36-39.

Megariati, M. (2014). Peningkatan Hasil Belajar Matematika Pada Materi Turunan Fungsi Menggunakan Teknik Probing Prompting Di Kelas XI IPA 1 Sekolah Menengah Atas Negeri 2 Palembang. Jurnal Pendidikan Matematika Sriwijaya, 5(1), 122232.

Murtiyasa, B. (2016). Isu-Isu Kunci dan Tren Penelitian Pendidikan Matematika.

Mutmainnah, S., Ali, M., \& Napitupulu, N. D. (2016). Penerapan Teknik Pembelajaran Probing-Prompting Untuk Meningkatkan Hasil Belajar Fisika pada Siswa Kelas VIIIA SMP Negeri I Banawa Tengah. JPFT (Jurnal Pendidikan Fisika Tadulako Online), 2(1), 38-43.

Pratiwi, R., Hikmawati, H., \& Gunada, I. W. (2019). Pengaruh Model Pembelajaran Probing Prompting Berbantuan Video Terhadap Hasil Belajar Dan Kemampuan Berpikir Kritis Peserta Didik. Jurnal Pendidikan Fisika Dan Teknologi, 5(2), 213-220.

Sulistiyono, A. (2011). Penggunaan Model Pembelajaran Probing-Prompting Sebagai Upaya Untuk Meningkatkan Hasil Belajar Siswa Kelas X. 5 Pada Mata Pelajaran Sejarah Kelas X Di SMA $N 1$ Bangsri Kabupaten Jepara Tahun Ajaran 2010/2011. Universitas Negeri Semarang.

Susanti, E. (2017). Penerapan Model Pembelajaran Probing-Prompting untuk Meningkatkan Kemampuan Berpikir Kritis Matematis Siswa Kelas XI. IPA MAN 1 Kota Bengkulu. Jurnal Pendidikan Matematika Raflesia, 2(1).
Swarjawa, I. W. E., Suarjana, M., \& Garminah, N. N. (2013). Pengaruh Model Pembelajaran ProbingPrompting Terhadap Hasil Belajar IPA Siswa Kelas V di SD Negeri 1 Sebatu. Mimbar PGSD Undiksha, 1(1). 